\title{
Mapping and Analyzing the Park Cooling Effect on Urban Heat Island in an Expanding City: A Case Study in Zhengzhou City, China
}

\author{
Huawei Li ${ }^{1,2, * \mathbb{C}}$, Guifang Wang ${ }^{1}$, Guohang Tian ${ }^{2}$ and Sándor Jombach ${ }^{1}$ \\ 1 Department of Landscape Planning and Regional Development, Faculty of Landscape Architecture and \\ Urbanism, Szent István University, 1108 Budapest, Hungary; guifang.wang@phd.uni-szie.hu (G.W.); \\ jombach.sandor@tajk.szie.hu (S.J.) \\ 2 Department of Landscape Architecture, College of Forestry, Henan Agricultural University, \\ Zhengzhou 450002, China; tgh@henau.edu.cn \\ * Correspondence: li.huawei@phd.uni-szie.hu
}

Received: 29 December 2019; Accepted: 11 February 2020; Published: 14 February 2020

\begin{abstract}
The Urban Heat Island (UHI) effect has been extensively studied as a global issue. The urbanization process has been proved to be the main reason for this phenomenon. Over the past 20 years, the built-up area of Zhengzhou city has grown five times larger, and the UHI effect has become increasingly pressing for the city's inhabitants. Therefore, mitigating the UHI effect is an important research focus of the expanding capital city of the Henan province. In this study, the Landsat 8 image of July 2019 was selected from Landsat collection to obtain Land Surface Temperature (LST) by using Radiative Transfer Equation (RTE) method, and present land cover information by using spectral indices. Additionally, high-resolution Google Earth images were used to select 123 parks, grouped in five categories, to explore the impact factors on park cooling effect. Park Cooling Intensity (PCI) has been chosen as an indicator of the park cooling effect which will quantify its relation to park patch metrics. The results show that: (1) Among the five studied park types, the theme park category has the largest cooling effect while the linear park category has the lowest cooling effect; (2) The mean park LST and PCI of the samples are positively correlated with the Fractional Vegetation Cover (FVC) and with Normalized Difference Water Index (NDWI), but these are negatively correlated with the Normalized Difference Impervious Surface Index (NDISI). We can suppose that the increase of vegetation cover rate within water areas as well as the decrease of impervious surface in landscape planning and design will make future parks colder. (3) There is a correlation between the PCI and the park characteristics. The UHI effect could be mitigated by increasing of park size and reducing park fractal dimension (Frac_Dim) and perimeter-area ratio (Patario). (4) The PCI is influenced by the park itself and its surrounding area. These results will provide an important reference for future urban planning and urban park design to mitigate the urban heat island effect.
\end{abstract}

Keywords: park cooling effect; park characteristic; urban heat island; land surface temperature; Zhengzhou; expanding city

\section{Introduction}

The Urban Heat Island (UHI) problem has been studied for more than 200 years since it was discovered in 1818 [1]. It refers to the phenomenon that the temperature of urban areas is higher than the temperature of its surrounding area [2-4]. The main reason for this phenomenon is the process of urbanization, as the vegetation is replaced with the built-up area during urban development [5]. This process leads to changes in the physical properties of the surface structure which modifies the thermal environment of urban areas. At present, urbanization is a major driving force within developing 
countries and their rapid urban growth towards becoming a developed nation. Taking China as an example, according to the National Bureau of Statistics of China, the urbanization rate in China was $59.58 \%$ in 2018 . This number is $12.58 \%$ higher than in 2008 . This high-speed urbanization had led to widespread UHI problems in China [6]. With this rapid increase in urbanization has come an increase in energy consumption, with individuals attempting to reduce these adverse temperature effects (e.g., air conditioning, private vehicle usage). As a consequence, higher energy consumption based on coal power plants may result in air pollution, water pollution, and additional climate changes. More specifically, UHI compromised the health and life quality of citizens [7].

Generally speaking, UHI can be measured by two methods: one of them is Surface UHI (SUHI); the other one is atmospheric UHI. Atmospheric UHI is defined into two different types: canopy layer UHI and boundary layer UHI [8,9]. From studies on the UHI effect, SUHI is widely used to characterize the UHI effect in the case of regional or urban studies. Due to the development of remote sensing technology, a high number of studies used satellite imagery to derive land surface temperature (LST) [6,10-12]. Concerning the investigation of UHI characteristics and changes in large-scale, these studies mainly focus on: (1) The spatial distribution of UHI; (2) the methods of satellite image inversion; (3) the relationship between land use land cover (LULC) and LST [13]. Furthermore, landscape pattern analysis in a regional scale was also proved to be a proper method in UHI research [14].

However, in small-scale UHI studies, the UHI is mainly characterized by the actual measured air temperature [15-17]. These kinds of studies mainly focused on the temperature difference between the green space and other land types, and the method of characterizing UHI intensity. In addition, some studies add microclimate factors and use the Local Climate Zone (LCZ) factors $[3,18]$ to investigate UHI. These microclimate conditions such as wind speed, wind direction, humidity, solar light intensity, surface reflectance and other localized effects on temperature [19-21]. Those studies showed that the green space cools the air due to the transpiration of the plants, which contributes to low UHI. In addition, local wind speed and wind direction also modify air temperature. The higher the surface albedo, the lower the temperature is found to be [22]. Besides the complexity of local climate and related environmental conditions the measurement of air temperature is limited by the monitoring system, including pieces of equipment, experts, method and such factors. The accuracy of data collection is always a key factor and it is almost impossible to conduct ideal UHI research on a wide range of space-time scales. These data sources are however very useful in understanding the generalized sources of data studied.

In the studies of Urban Cold Island (UCI) effects and UHI mitigation [23,24], two methods were used to quantify the cooling effect of green space and park areas. These are called Green space Cooling Intensity (GCI) and Park Cooling Intensity (PCI) $[25,26]$. GCI is defined as the temperature difference between green space and the average temperature of the whole study area. While the PCI usually determined as the temperature difference between the inside park area and its outside within a $500 \mathrm{~m}$ buffer area $[27,28]$. These two methods are used to describe the cooling effect of green spaces and parks. Studies also show that vegetation coverage has a significant effect on the reduction of UHI $[10,29,30]$. On top of this, the impervious surface area is positively correlated with LST and contributes the most to UHI $[10,31,32]$. Some studies use landscape factors to analyze the UCI and GCI on mitigating the UHI effect [33-35]. The parameters include shape index (Shape_ldx), fractal dimension (Frac_Dim) and landscape connectivity. One research study focused on the role of green space in reducing the UHI effect. This study looked at the distance changes of the green space cooling effect in relation to the characteristics of green space bodies with regards to size, perimeter, shape index, fractal demission, and UHI. The results of these studies showed that the cooling effect of green space is complex [25-27]. PCI related studies mostly used remote sensing imagery as base data. According to a study based partly on surrounding vegetation, water body and impervious surface [26], the cooling effect of parks is also depending on types of outside the park spaces. The air temperature is also employed to examine the cooling effect of parks on UHI [36,37]. It is also noted that the patch and pattern of a park has a relationship to the cooling effects that it has on the UHI it forms part of. Some researches employ the 
thermal conduct theory, a physical science methodology, to investigate the heat balance (between park and its surrounding area) when studying the urban thermal environment [38-40], this method of study can assist in providing a methodical approach to understanding the cooling effect of park.

At present, cities have grown exponentially. The actual scale and speed of China's overall urbanization process has never seen before in modern urban development. Super-large cities and megacities have become commonplace in China's inland areas. These big cities result in urban environment problems like UHI, For example, In Zhengzhou city, Studies showed that from 1996 to 2014, the average LST increased by $2.94{ }^{\circ} \mathrm{C}$ in Zhengzhou city [41], and the UHI change was positively correlated with land cover changes over this period. It has also been proven that the increase of the built-up urban areas [42] showed a negative correlation with the vegetation cover rate in Zhengzhou. UHI studies in the city of Zhengzhou analyzed many factors, but these neglected to focus on green space categories types while also not using large enough sample sizes.

In this paper, we selected the latest cloud-free satellite image acquired on 07 July 2019 as base data to focus on the UHI effect characteristics in the megacity of Zhengzhou. Choosing 123 parks as samples identified though high-resolution Google Earth images, we investigated the cooling effect characteristics of the chosen parks. The cooling intensity and park buffer sizes were studied, and the correlation between the park patch metrics and the cooling intensity was explored. We aimed to: (1) Analyze the PCI differences among five park types; (2) analyze the park LST and its relation to vegetation, water surface area and impervious surface factors; (3) analyze park LST and its relation to park patch indices; (4) analyze PCI and its relation to park patch indices and impact factors of park surrounding areas. As a whole, this research was conducted to analyze the relationship between park cooling effect and its related impact factors, to understand UHI characteristics in Zhengzhou. The intention of this analyses understanding is to give guidance for stakeholders, as well as to the developers of urban planning strategies to address UHI.

\section{Study Area}

Zhengzhou $\left(34^{\circ} 16^{\prime}-34^{\circ} 58^{\prime} \mathrm{N}, 112^{\circ} 42^{\prime}-114^{\circ} 14^{\prime} \mathrm{E}\right)$ is the capital city of Henan Province in Central China. It is south of the North China Plain and the Yellow River (Figure 1). It is one of the largest transportation hubs in China. The population of the city was approximately 9.56 million, according to the 2017 census [43]. The population density is the second highest in China. Zhengzhou lies in the north warm-temperate zone, characterized by a warm climate, because of this it has four distinct seasons, characterized by a dry spring (March-May), and a hot and rainy summer (June-September).

Urbanization was taken place at a rapid rate in the past few decades in Zhengzhou city. This makes it an ideal sample city to understand the problems which are seen across urbanized cities across the world. Population growth and government level development policy is the main driver for the dramatic urban expansion. For example, the population of Zhengzhou increased from 4.2 Million in 1978 to 9.9 million in 2017, which means more than 100\% growth in 40 years [44]. At the same time, Zhengzhou was designated as the core city of "Central Plain Economic Zone" and "Central Plains Urban Agglomeration." In 2016, Zhengzhou was officially named as the eighth "National Central City" in 2017 by the central government in China. This state-level policy provides a significant number of opportunities for the development of Zhengzhou. 

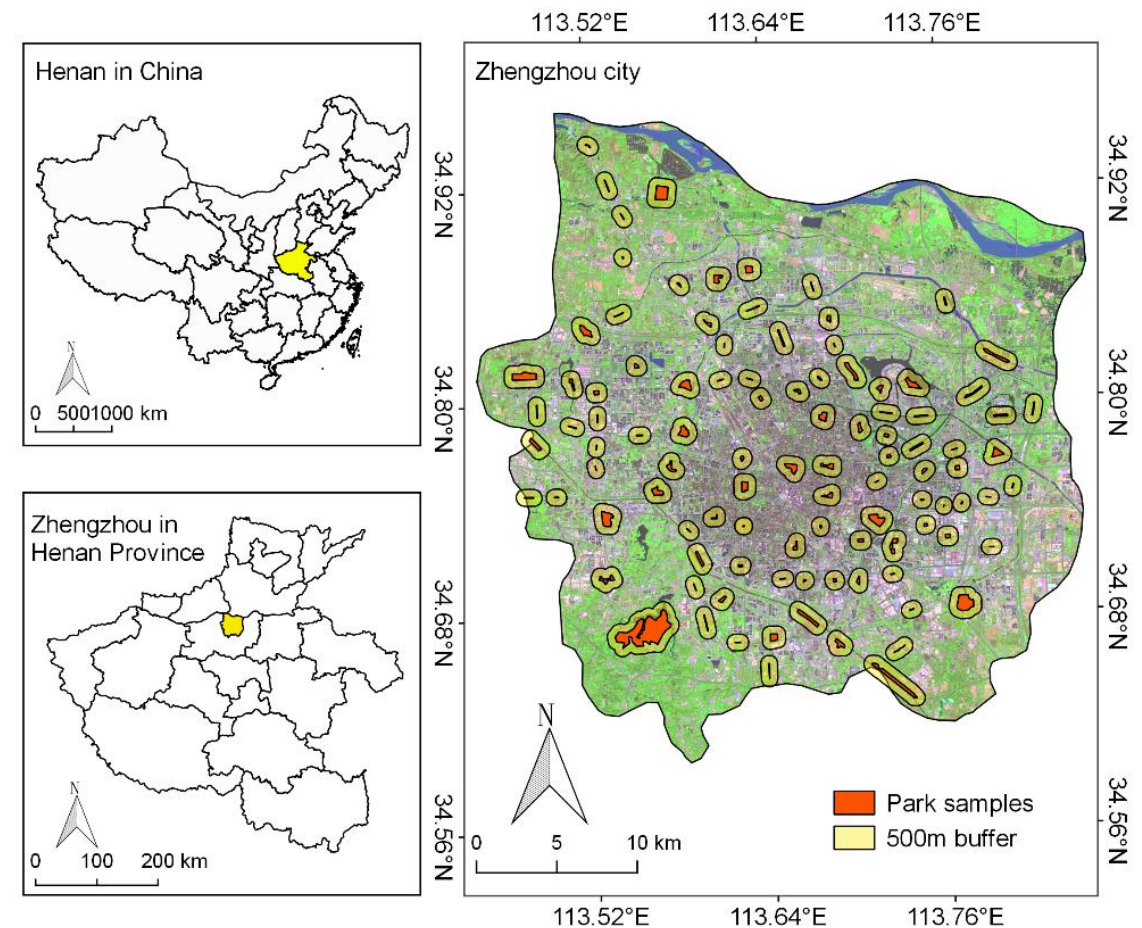

Figure 1. Location of the study area Zhengzhou, Henan province in China and 123 park samples in Zhengzhou.

\section{Data Sources and Methods}

\subsection{Data Used}

In this work, one satellite image from USGS (earthexplorer.usgs.gov; Table 1) was used to extract Land Surface Temperature (LST) in Zhengzhou city. The Landsat 8 image was selected from a collection of summer images obtained between May and September in an attempt best considering the LCZ of the study area. It is cloud-free and has high quality with a resolution up to 30 meters. In conjunction with the satellite image, we also employed additional base maps obtained from high-resolution Google Earth images, low altitude UAV images, and the official urban land use map of Zhengzhou city.

Table 1. Characteristics of the Landsat-8 OLI image used in this study.

\begin{tabular}{ccccc}
\hline Date & Path/Row & Band & Wavelength $(\boldsymbol{\mu m})$ & Resolution $(\mathrm{m})$ \\
\hline 07 July 2019 & 124/36 & Band 1-Ultra Blue & $0.435-0.451$ & 30 \\
& & Band 2-Blue (B) & $0.452-0.512$ & 30 \\
& Band 3-Green (G) & $0.533-0.590$ & 30 \\
& Band 4-Red (R) & $0.636-0.673$ & 30 \\
& Band 5-Near Infrared (NIR) & $0.851-0.879$ & 30 \\
& & $1.566-1.651$ & 30 \\
& Band 6-Shortwave Infrared (SWIR) 1 & 30 \\
& Band 7-Shortwave Infrared (SWIR) 2 & $2.107-2.294$ & $100 *(30)$ \\
\hline
\end{tabular}

* Native resolution was $100 \mathrm{~m}$, TIRS thermal constant of band 10: $\mathrm{K}_{1}=774.89 ; \mathrm{K}_{2}=1321.08$.

\subsection{Retrieval of LST and the Average LST Calculation}

The radiative transfer equation (RTE) method of land surface temperature (LST) has been widely recognized and generally divided into five steps [45-48]:

(1) Conversion to Spectral Radiance [49];

(2) Conversion to top of Atmosphere Radiance [49];

(3) Conversion to Top of Atmosphere Brightness Temperature [49]; 
(4) Calculation of Proportion of Vegetation [50];

(5) Estimation of estimate land surface emissivity (LSE) [48];

(6) Retrieval of land surface temperature (LST).

\subsection{Sample Selection}

Based on the classification applied in Chinese urban planning regulations and the distribution of parks in Zhengzhou city, this paper selected five functional types of parks, 123 (one hundred and twenty three) parks in total as study sites (Table 2). The parks boundaries were determined based on high-resolution Google Earth images and low-altitude UAV (drone) images. As the original spatial resolution of the Landsat thermal infrared band is $100 \mathrm{~m}$, we selected sample parks larger than 2 hectares.

Table 2. Statistics and details of 123 sample parks by types.

\begin{tabular}{cccccc}
\hline Types & Number & Percentage & $\begin{array}{c}\text { Maximal Area } \\
\text { (ha) }\end{array}$ & $\begin{array}{c}\text { Minimal Area } \\
\text { (ha) }\end{array}$ & Main Example \\
\hline Urban Park & 59 & $48 \%$ & 87.16 & 3.12 & City park, District park \\
Theme Park & 10 & $8 \%$ & 108.53 & 10.61 & Botanical garden, Zoo \\
Street Park & 28 & $23 \%$ & 25.26 & 1.23 & Pocket park, community park. \\
Linear Park & 19 & $15 \%$ & 62.02 & 2.13 & Riverside park, roadside park \\
Urban Square & 7 & $6 \%$ & 6.64 & 2.15 & Square \\
\hline
\end{tabular}

\subsection{Determination of the Park Cooling Intensity (PCI)}

Park Cooling Intensity (PCI) usually calculates the temperature difference between the inside and outside of the park [28,51,52]. It can be air temperature or land surface temperature. In this study, the PCI (units in ${ }^{\circ} \mathrm{C}$ ) was defined as the mean LST difference. Equation (1):

$$
\mathrm{PCI}=\Delta \mathrm{T}=\mathrm{T}_{\mathrm{u}}-\mathrm{T}_{\mathrm{p}}
$$

where $T_{u}$ is the mean LST of an urban area of the $500 \mathrm{~m}$ buffer zone outside of the park, and $T_{p}$ is the mean LST inside the park. The buffer zone includes the area around the park, which contains different land cover types: Buildings, roads, impervious surfaces, trees, and green spaces.

\subsection{Patch Descriptors of the Park}

In this paper, several indicators were applied to characterize the impact factors on PCI (Table 3). By using the ArcGIS 10.2 tools, we calculated fractal dimension (Frac_Dim), perimeter-area ratio (Patario) and shape index (Shape_ldx) in patch level. From the previous studies, those three indicators were used as the main patch metrics, and had been widely employed to analyze landscape patterns, both in class level and patch level [33-35]. These initial base studies were successful in demonstrating the characteristics of landscape patterns both in regional and local scale [53]. Here we investigated the relation of these indicators to park cooling effect in sample areas of Zhengzhou city. Low fractal dimension is described as simple, non-waving, straight boundaries, high fractal dimension means waving edges of park and surroundings. 
Table 3. Park metrics used in this study.

\begin{tabular}{ccc}
\hline Name & Equation & Description \\
\hline Perimeter-Area Ratio* & Paratio $=\frac{P i}{A i}$ & $\begin{array}{c}P_{i}=\text { perimeter }(\mathrm{m}) \text { of patch } i . A_{i}=\operatorname{area}\left(\mathrm{m}^{2}\right) \\
\text { of patch } i . \\
\text { Paratio equals the ratio of the patch } \\
\text { perimeter }(\mathrm{m}) \text { to area }\left(\mathrm{m}^{2}\right)[54] .\end{array}$ \\
\hline Landscape Shape Index* & Shape_Idx $=\frac{0.25 P i}{\sqrt{A i}}$ & $\begin{array}{c}\text { Landscape shape index provides a } \\
\text { standardized measure of total edge or edge } \\
\text { density that adjusts for the size of the } \\
\text { landscape [54]. }\end{array}$ \\
\hline Fractal Dimension Index * & Frac_Dim $=\frac{2 \ln (0.25 P i)}{\ln A i}$ & $\begin{array}{c}\text { Fractal Dimension Index reflects the extent } \\
\text { of shape complexity across a range of } \\
\text { spatial scales [54]. }\end{array}$ \\
\hline
\end{tabular}

Notes: * Source: FRAGSTATS: https://www.umass.edu/landeco/research/fragstats/documents/fragstats_documents.html.

In addition to the three indicators, we also used three indices to classify the satellite image of the study area (Table 4), which have been successfully proven by other researchers. The three indicators are Normalized Difference Water Index (NDWI) [55], Fractional Vegetation Cover (FVC) [56] and Normalized Difference Impervious Surface Index (NDISI) [57]. These indices can represent the surface coverage condition inside of the park.

Table 4. Spectral indexes of Landsat image used in this study.

\begin{tabular}{ccc}
\hline Name & Equation & Description \\
\hline NDWI & NDWI $=\frac{N I R-S W I R}{N I R+S W I R}$ & $\begin{array}{c}\text { Normalize Difference Water Index } \\
\text { (NDWI) is a remote sensing based indicator } \\
\text { sensitive to the open water surface and } \\
\text { water content of leaves [55]. }\end{array}$ \\
\hline NDVI & NDVI $=\frac{N I R-R}{N I R+R}$ & $\begin{array}{c}\text { Normalize Difference Vegetation Index } \\
\text { (NDVI) is used o determine the density of } \\
\text { green on a patch of land [10]. }\end{array}$ \\
\hline FVC * & FVC $=\frac{N D V I i-N D V I m i n}{N D V I m a x-N D V I m i n}$ & $\begin{array}{c}\text { The Fractional Vegetation Cover (FVC) is } \\
\text { mainly depicts the vegetation abundance of } \\
\text { ground surface [58]. }\end{array}$ \\
\hline MNDWI & MNDWI $=\frac{G-S W I R}{G+S W I R}$ & $\begin{array}{c}\text { Modified Normalize Difference Water } \\
\text { Index (MNDWI) is an indicator used to } \\
\text { determine the open water area [59]. }\end{array}$ \\
\hline NDISI & NDISI $=\frac{T I R-[(M N D W I+N I R+S W I R) / 3]}{T I R+[(M N D W I+N I R+S W I R) / 3]}$ & $\begin{array}{c}\text { Normalize Difference Impervious Surface } \\
\text { Index (NDISI) indicator is used to estimate } \\
\text { impervious surface [57]. }\end{array}$ \\
\hline
\end{tabular}

Notes: * Where NDVIi is NDVI value of a pixel i; NDVImin is minimum value; NDVImax is maximum value. $R$, G, NIR, SWIR, TIR, (Table 1).

\subsection{Analysis Methods}

Statistical analysis was performed by SPSS 25.0 and Microsoft Excel. After retrieval of the LST, FVC, NDWI, NDISI values from the satellite image, QGIS was used to obtain summarized values of each sample area. Then SPSS was applied to conduct the linear regression analysis to quantify the relationship among LST, FVC, NDWI, NDISI, and PCI. For the park patch metrics calculation, we used the ArcGIS spatial analysis method to obtain the following parameters of each sample park: area, paratio, shape index and fractal dimension. The same linear regression analysis was made to PCI and LST. Additionally, the related coefficient was also utilized to detect and verify the result.

For the regression analyses, first, we use Pearson correlation analysis to obtain the main significant impact factors, and then analyze the regression relationship between the two factors in a targeted manner to find the optimal curve fitting model. The final presented fitting model (Figures 3-6) is the best explanation of the relationship between specific factors within the selected sample park. 


\section{Results}

\subsection{Relation between Park Types, LST and PCI}

Following the method in Section 3.2, the LST map based on the 07 July 2019 satellite image was derived (Figure 2a). Generally, the mean LST of the parks was lower than the mean LST of Zhengzhou city. We analyzed the PCI of all the selected samples by comparing the five park types (Table 2), and results show that the PCI of five park types were different (Table 5): The average temperature of the theme park category is $30.01{ }^{\circ} \mathrm{C}$; noticeably it is $2.14{ }^{\circ} \mathrm{C}$ lower than the average temperature of Zhengzhou city. Its cooling effect is the strongest, where the average PCI reached $2.76{ }^{\circ} \mathrm{C}$. The urban squares had the highest temperature, with an average LST of $32.13{ }^{\circ} \mathrm{C}$, which is still $0.02{ }^{\circ} \mathrm{C}$ lower than the average LST in Zhengzhou.
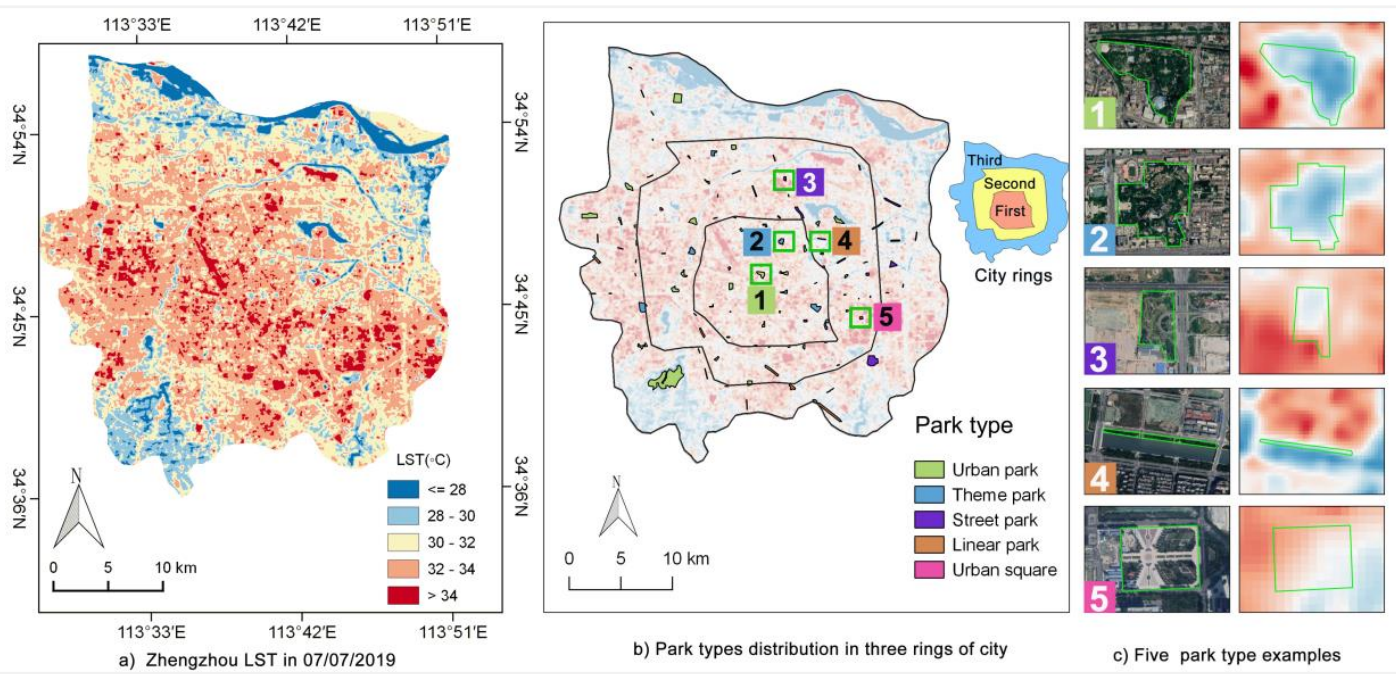

Figure 2. (a) LST map of Zhengzhou city in 07 July 2019; (b) Distribution of 123 parks samples; (c) Five park type examples: 1-urban park; 2-theme park; 3-street park; 4-linear park; 5-urban square.

Table 5. Statistics of LST and average PCI in different park types.

\begin{tabular}{ccccccc}
\hline Code & Type & Number & $\begin{array}{c}\text { Mean LST } \\
\left({ }^{\circ} \mathbf{C}\right)\end{array}$ & Max $\left({ }^{\circ} \mathbf{C}\right)$ & Min $\left({ }^{\circ} \mathbf{C}\right)$ & $\begin{array}{c}\text { Average PCI } \\
\left({ }^{\circ} \mathbf{C}\right)\end{array}$ \\
\hline 1 & Urban park & 59 & 30.43 & 33.63 & 27.63 & 1.71 \\
2 & Theme park & 10 & 30.01 & 34.62 & 25.97 & 2.76 \\
3 & Street park & 28 & 31.32 & 37.80 & 25.34 & 0.8 \\
4 & Linear park & 19 & 31.47 & 35.42 & 28.56 & 0.64 \\
5 & Urban square & 7 & 32.13 & 33.90 & 31.10 & 1.44 \\
6 & Zhengzhou city & - & 32.15 & 46.09 & 20.11 & - \\
\hline
\end{tabular}

The result (Table 5) showed that PCI of the theme park category was the largest, this is related to the content of the theme park. Linear parks had the lowest cooling effect; the PCI value was only $0.64{ }^{\circ} \mathrm{C}$. Meanwhile, the cooling effect of the street park category is also at a comparatively low level, with its PCI only $0.16^{\circ} \mathrm{C}$ higher than the PCI of the street park group. The PCI of the urban square category was in the middle, it reached $1.44{ }^{\circ} \mathrm{C}$, but its average LST was the hottest among the five types. So based on the results, we can conclude that theme parks have the most substantial cooling effect in Zhengzhou city, while the linear park category contributes with a less cooling effect.

\subsection{Relation between Park LST and Its Impact Factor}

First, we analyzed the relation between park LST and the spectral indices inside the park. The results showed that the mean park LST was significantly related to the FVC, the NDISI, and the 
NDWI (Figure 3). The cooling effect of the park is directly proportional to the park's vegetation percentage $\left(R^{2}=0.489\right)$, indicating that more vegetation cover makes parks cooler (Figure 3c). For example, Xiongerhe park's FVC has one of the highest values (0.408), while the mean temperature is the lowest $\left(28.06^{\circ} \mathrm{C}\right)$. Moreover, the average PCI of Xiongerhe shows it is much colder $\left(2.18^{\circ} \mathrm{C}\right)$ than its surrounding area. The results showed that the NDWI plays a negative role in park LST (Figure $3 \mathrm{~b}$ ), indicating that the NDWI value strengthens the cooling effect of the park. On the contrary, the NDISI has a relatively positive effect on park LST. From the regression model between LST and NDISI, the coefficient of determination $\left(R^{2}\right)$ reached 0.926 (Figure 3c), revealing that the impervious surfaces have a significant impact on park temperature. The impervious surface is the main contributor to warm conditions of parks. We can conclude that water and vegetation have a positive impact on park cooling roles in Zhengzhou while the impervious surface increases the park warmth.
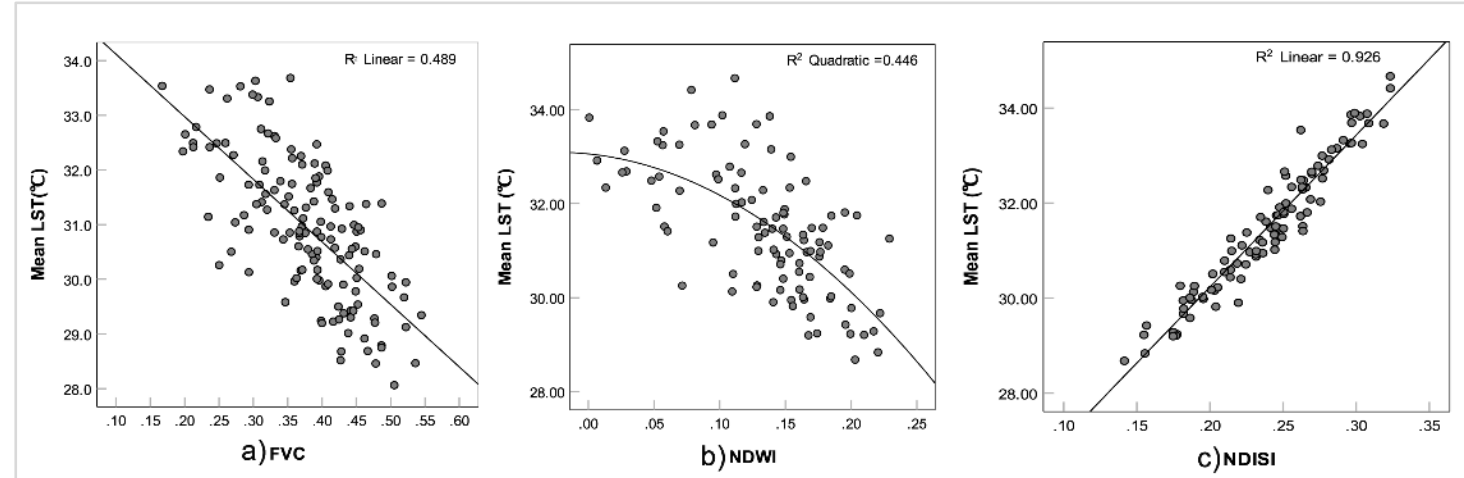

Figure 3. Regression analysis among mean park LST and, (a) FVC, (b) NDWI, (c) NDISI.

Secondly, we analyzed the relation between park LST and park characteristics (patch metrics). The result of the analysis shows that patch metrics have relations to park LST. From Figure 4, park size is negatively correlated with the mean park LST (Figure $4 a, R^{2}=0.308$ ), which means the park size is one of the main factors of LST. We can see from the Figure 4a, if the park size was larger than 40 ha, the average LST was below $31^{\circ} \mathrm{C}$, and the average LST appeared in a wide temperature range among the parks with size below 20 ha. Fractal dimension (Frac_Dim) and perimeter area ratio (Paratio) show a positive correlation with the park LST, and the coefficient of determination $\mathrm{R}^{2}$ is $0.191,0.280$. This indicates that these two factors also have an impact on LST. The shape index has no significant correlation with park LST (Figure 4d). For example, the park with a maximum shape index (2.13) has the same LST $\left(28.80^{\circ} \mathrm{C}\right)$ as parks with the lowest shape index (1.21) (Figure 4e). From the results, we can conclude that the park size and perimeter-area ratio play a more critical role than other patch metrics in the sample parks of Zhengzhou city. 

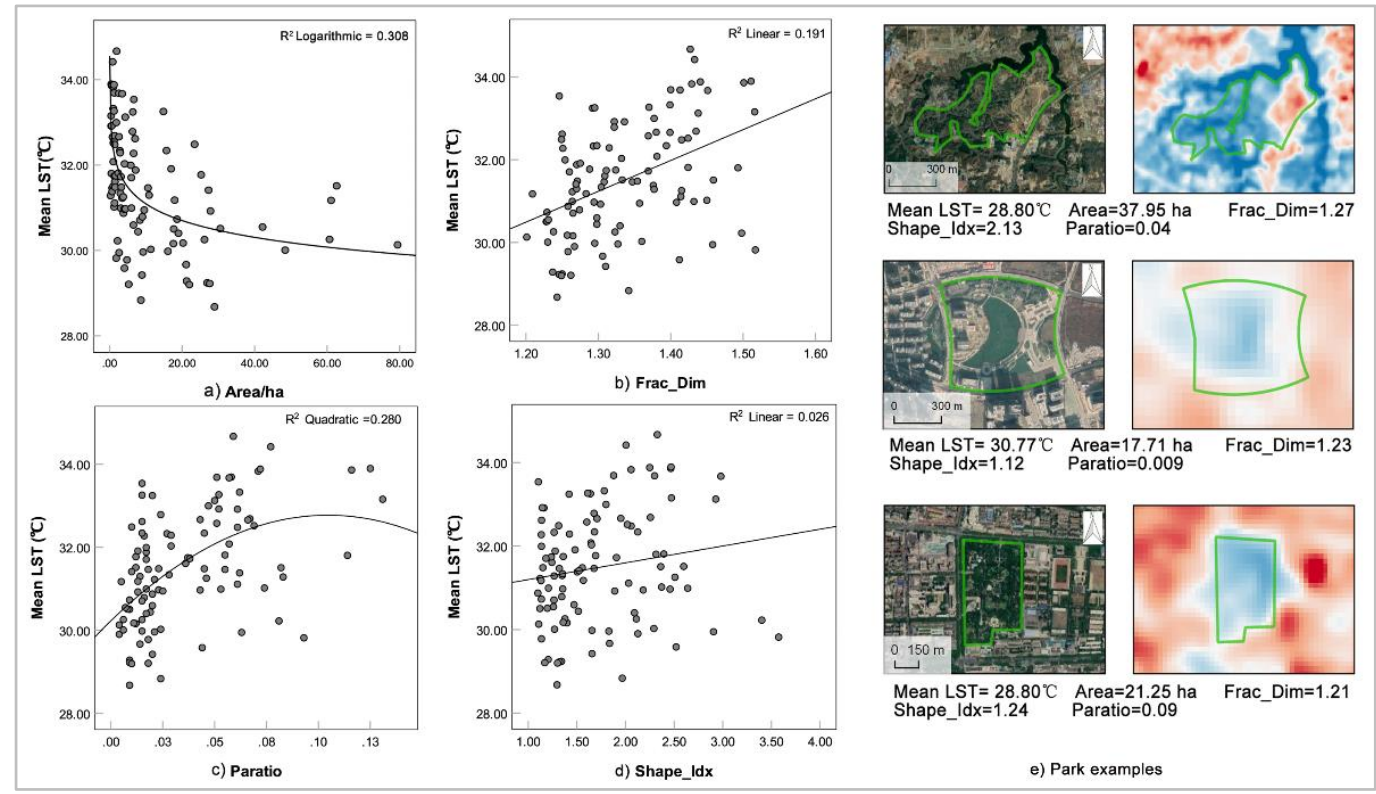

Figure 4. Regression analysis among mean park LST and park characteristics: (a) Size; (b) Frac_Dim; (c) Paratio; (d) Shape_Idx; (e) Three selected park examples.

\subsection{Relation between PCI and Its Impact Factor}

First, we analyzed the relation between PCI and the spectral indices inside the park. The results of correlation with PCI are shown in Figure 5. We found that FVC has a positive effect on PCI: the more FVC we have, the higher PCI appears. However, the coefficient of determination $\mathrm{R}^{2}$ is only 0.237 . This means that PCI only partly depends on vegetation cover. Figure $5 b$ indicates that higher NDWI contributes to higher PCI, this quadratic regression analysis coefficient of determination $\left(R^{2}\right)$ is 0.433 . Among the three factors, the NDISI has the strongest relationship with PCI (Figure 5c), the coefficient $\left(\mathrm{R}^{2}\right)$ is 0.618 , which means the impervious surface has a significant influence on PCI. So, from the park spectral indices results, we can recognize the park vegetation and water percentage play a decisive role in PCI, while the high impervious surface reduces the cooling effect of parks.

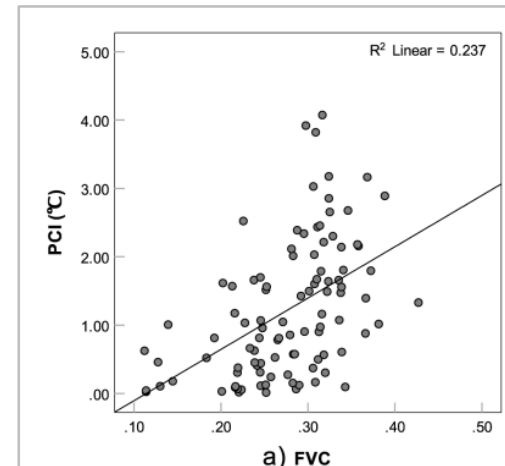

a) Fvc

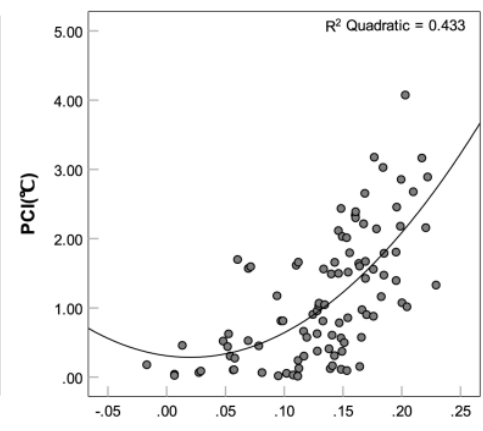

b) NDWI

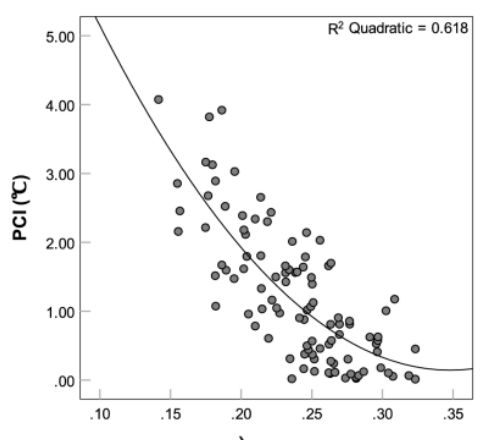

c) NDISI

Figure 5. Regression analysis of park PCI and (a) mean FVC; (b) mean NDWI; (c) mean NDISI.

Secondly, we analyzed the relation between PCI and park characteristics (patch metrics). PCI has a complex correlation with park patch metrics (Figure 6). Among the four analysis results, the size, fractal dimension (Frac_Dim), and perimeter area ratio (Paratio) regression coefficient of determination $R^{2}$ is $0.321,0.355,0.439$, respectively (Figure 6a-c) which means those three factors contribute to the $\mathrm{PCI}$ in general. While the shape index showed no significant correlation, as its linear model $\mathrm{R}^{2}$ is 0.089 (Figure 6d). Park shape index does not contribute to PCI among the selected sample parks of Zhengzhou. 


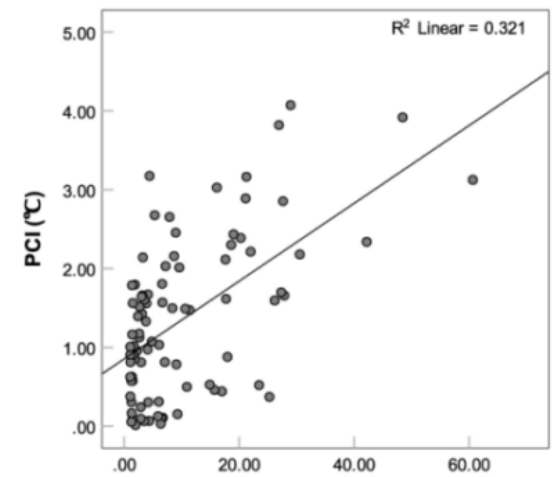

a) Area (ha)

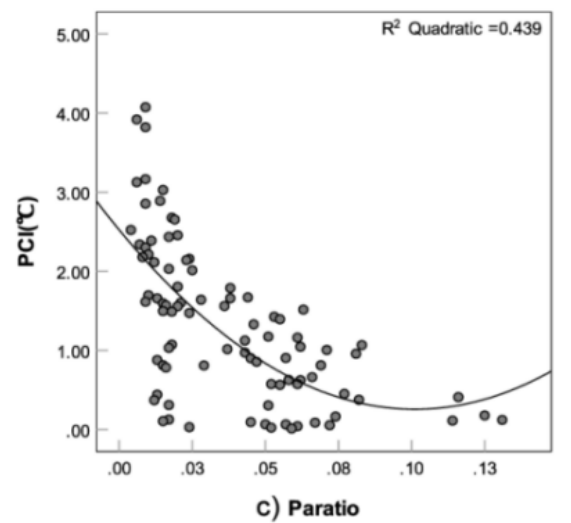

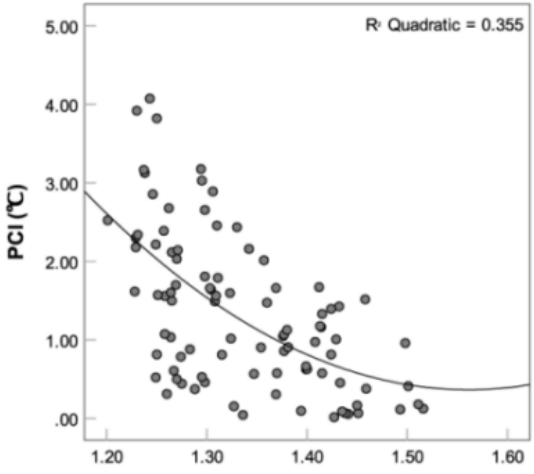

b) Frac_Dim

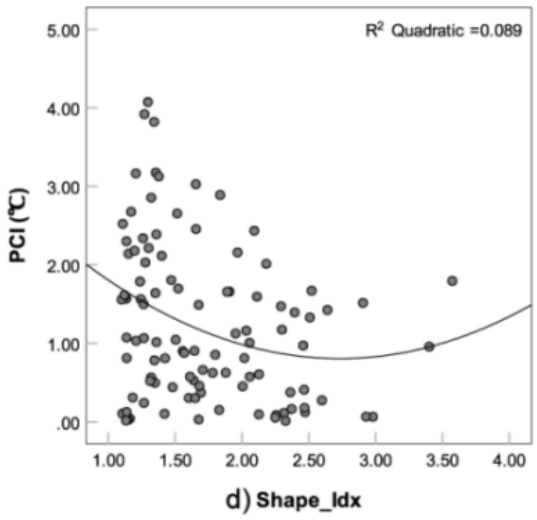

Figure 6. Regression analysis among PCI and mean park characteristics: (a) Size; (b) Frac_Dim; (c) Paratio; (d) Shape_Indix.

Thirdly, we investigated the relationship between PCI and the impact factor of the park surrounding area. In order to analyze the impact of PCI and the type of land cover around the parks, we selected 43 parks with similar mean LST (within the range of $29.0^{\circ} \mathrm{C}-30.0^{\circ} \mathrm{C}$ ) from 123 samples (Figure 7). For external land cover types, we use spectral indicators: NDVI, NDWI, NDISI to measure vegetation, water coverage and impervious surfaces of the surroundings.
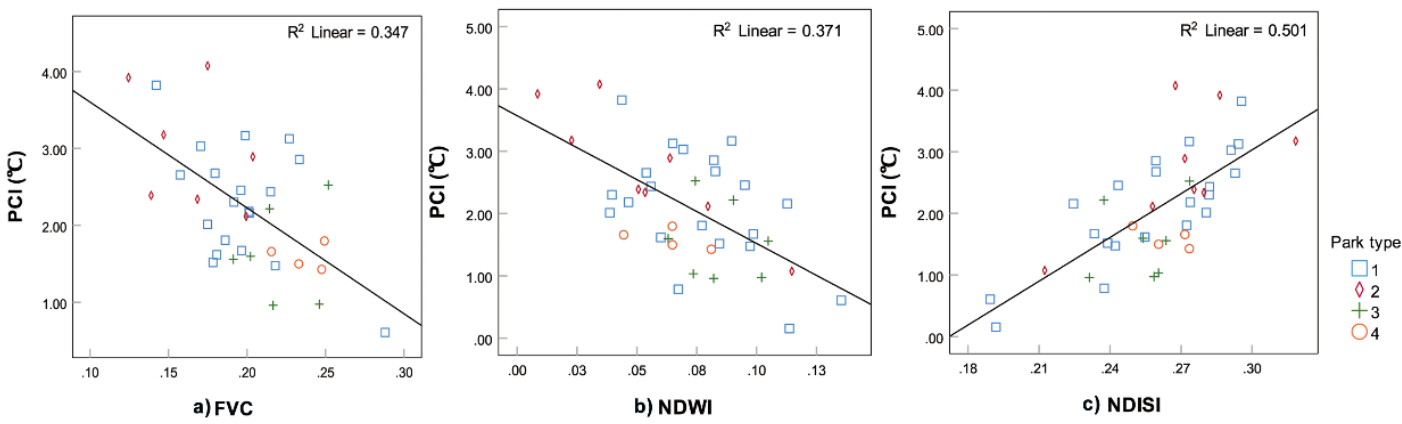

Figure 7. Regression analysis between the PCI and the impact factor of park surrounding area $(500 \mathrm{~m}$ buffer). (a) surrounding FVC; (b) surrounding NDWI; (c) surrounding NDISI, park type: LST range $\left(29-30{ }^{\circ} \mathrm{C}\right.$ ) based selection of 43 parks: 1-urban park; 2-theme park; 3-street park; 4-linear park.

The linear regression analysis was used to analyze the PCI relationship with the three factors outside the parks. The results show (Figure 7) that in the case of parks within the LST range of $29-30^{\circ} \mathrm{C}$ the type of land cover around the park has a significant impact on PCI. PCI has a negative correlation with surrounding vegetation and water bodies, and a positive correlation with impervious surfaces in cases we analyzed from elements within the same LST range $\left(29-30^{\circ} \mathrm{C}\right)$. This shows that PCI is not only affected by the internal factors of the park but also related to the surrounding environment. 
In addition, we analyzed the location factor on PCI based on the city rings. Zhengzhou city has three rings defined by the urban ring road (Figure $2 b$ ), the first ring is the urban center area, which is denser than the other two. The parks in the first ring have the highest average PCI (Figure 8a), as the land cover types in the urban center are mostly commercial areas and built-up areas with tall buildings and impervious surfaces, which are warmer than other areas of the city. The third ring is the low-density urban area and is covered with more green spaces and mostly low-rise buildings. We recognized that $\mathrm{PCI}$ is also influenced by the location factor, which is partly in relation to the different land cover types of park surroundings.
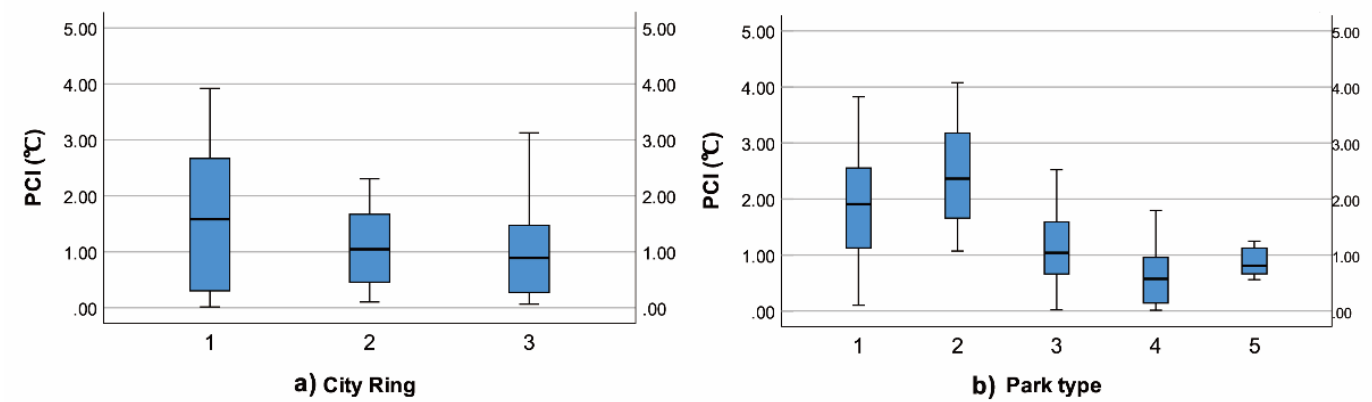

Figure 8. Analysis between PCI and location factor and park types (all 123 samples). (a) PCI and park location in three city rings; (b) PCI and five park types: 1-urban park; 2-theme park; 3-street park; 4-linear park; 5-urban square.

The park type can be defined based on different surrounding types, for example, linear park is mostly located, and surrounded by road or river, the urban square is usually located in the high-density area. Due to this reason, the linear park and urban square show low PCI (Figure 8b). These results are mainly attributed to the different surrounding environments and land cover of different park types. So, we can conclude that $\mathrm{PCI}$ is also related to the surrounding land cover types.

\section{Discussion}

\subsection{Impact Factors of PCI}

The results of Section 4.1 show that park types can have a different impact on PCI. Among the five park types, the theme park category has the highest PCI, which reaches $2.76{ }^{\circ} \mathrm{C}$. The reason is that the theme park has higher vegetation cover and higher water surface coverage than other types. For instance, Zhengzhou Botanical Garden, where the mean FVC, NDWI, NDISI is 0.40, 0.16, 0.19, respectively. More specifically, the vegetation coverage is higher than $50 \%$, and the diversity of species is high as well, as its primary function is science education for citizens. The linear park category has the weakest PCI. This may be because the linear parks (Figure 2c, 4-linear park) are mostly riverside green spaces, or very close to the water surface (e.g., Riverside Park). In case of linear parks in Zhengzhou, there is small LST difference between the park and its neighboring water surfaces. Therefore, the linear park type's average PCI of is the lowest.

For the results of PCI and its impact factors, we have similar conclusions. The FVC, NDWI, NDISI regression coefficient of determination $\left(R^{2}\right)$ are $0.237,0.433,0.618$, respectively. This means the complex correlation between PCI and park characteristics cannot be represented only by those three factors. The park patch metrics (size, fractal dimension, perimeter-area ratio, and shape index) also could not determine alone the PCI variance. As we can recognize from Section 4.3 PCI is also related to the types of the surrounding areas (Figures 6-8). High FVC and NDWI in surrounding areas make the buffer LST closer to the park internal LST, which results in low PCI. There is a positive effect between PCI and surrounding NDISI, related to the surrounding land cover types. As the result shown in Figure 8, the location factor and park type factor also effect PCI. 
The cooling effect of the park can be explained from the perspective of thermal balance [39]. We can use the heat transfer theory (Bowen ratio) as an analogy to explain some of the results of this article. The Bowen ratio is the ratio of sensible heat flux to latent heat flux [60]. The surrounding areas are heat sources because the heat capacity of these is significantly smaller than the heat capacity of the parks. In heat conduction, the thermal power (sensible heat flux) absorbed by the parks from the surroundings should be equal to the excess energy resistance by photosynthesis and transpiration (latent heat flux), thus the heat conduction reaches balance. A larger green space means more energy is dissipated which results in more conducted thermal energy. Therefore, parks with large sizes, high vegetation coverage, and high water surface rate have greater energy resistance, which reduces Bowen ratio, and finally, result in higher PCI.

Furthermore, the heat conduction can also explain why parks with high Paratio and fractal dimension have lower PCI. High Paratio and fractal dimension mean that the park boundary is in a large contact surface (complex edges) with the surrounding heat sources, which is conducive to heat conduction and heat exchange. This causes temperature difference decreases, resulting in lower PCI. At the same time, this can also explain the relationship between PCI and surrounding land cover. The ambient temperature also affects the heat transfer. As a whole, to increase the cooling effect of the park, it is recommended to consider the factors of the park itself, improve the resistance to the thermal environment, and increase latent heating, so as to reduce the heat island.

\subsection{Impact Factors of Park LST}

The results of Section 4.2 reveal that high FVC, high NDWI will contribute to low park LST. Those findings are consistent with the results of the previous studies at the city level $[57,59,61]$. This is because the high rate of vegetation cover stores less solar energy and thus solar heat gain. The plants photosynthesis and transpiration absorb the heat during those processes [5]. Those altogether lead to lowering the park LST. In remote sensing technology, NDWI mostly represents the water body and the vegetation surface. This result also coincides with the findings in another study [62]. A recommendation for planning purposes would be to increase the vegetation and water body ratio to decrease the park LST. As NDISI had been used successfully in previous studies [57,63], we have used it to analyze the relationship of impervious surface to mean park LST. The results show that NDISI has a strong correlation with mean park LST. The reason is that the impervious surfaces have high thermal conductivity and low heat capacity [6], which lead to high LST. However, the impervious surface is an important part of park design, but we should optimize the surface rate within the design.

In terms of the results of park characteristics like the size, fractal dimension (Frac_Dim), perimeter-area ratio (Paratio), and shape index (Shape_ldx) in patch level have an impact on park LST, and those independent factors reflect the park morphology. From the results, we can recognize that large size, low Perimeter-Area ratio, and low fractal dimension decreases park LST.

Despite the practical findings in this article, we have some limitations to some extent. First, the data of satellite images have its limitation to interpret the surface thermal environment; because the temperature also relates to the microclimate factors such as wind speed and direction, humidity. The results in this paper can also be explained that park LST impact factors are the main reasons. Nevertheless, from the impact factors of park LST and PCI, the coefficient of determination $\left(\mathrm{R}^{2}\right)$ are not high. For instance, the FVC and NDWI regression value to mean park LST are 0.489 and 0.446 , and it can only reveal that vegetation cover and water surface can explain only less $50 \%$ of the mean park LST variance. But the NDISI indicators have a significant relation to park LST, as its regression coefficient is 0.926 , which means the impervious surface is the most crucial factor that brings higher LST in Zhengzhou. The analysis results of park patch metrics (size, fractal dimension, perimeter-area ratio, and shape index) and their relationship to park LST is even more complicated. Moreover, previous studies showed that even the meteorological factors (wind speed, wind direction, humidity) could influence the PCI value when we use air temperature to evaluate park cooling effect $[19,64,65]$. In terms of future study on the park cooling effect, we should put those aspects into consideration. 
In conclusion, in terms of the UHI effect mitigation, the results on park LST are more important for planners than the results of PCI. PCI is related to the factors both inside and outside the park, but the surrounding areas are far more difficult to modify or redesign. It is clear that for planners the better option is to reduce the park LST to increase the cooling effect and mitigate the UHI effect. A future research path can focus on the analysis of parameters (e.g., vegetation types, tree coverage, height of vegetation) within the park. In landscape design, it is necessary to investigate the cooling effects of various green space design examples. Further research can deal with the vegetation cover rate analysis within a green space to optimize design from UHI point of view at local scale.

\subsection{Implications for Urban Planning and Landscape Design}

According to the results we can give a reference to urban planning and landscape design in the future. The planner and designer can follow the recommendation:

(1) In urban planning and design: increase the number of theme park types in the city, increase the park size and number in a new town/district planning;

(2) In landscape design and renewal: increase the park size, plan more vegetation and water area in parks, as well as reduce the impervious surface. At the same time, in case we follow PCI aspect of decreasing UHI we could make the park shape less complex in site design with less curving boundaries and less waving edges (based on Frac_Dim), we can consider the options of lowering the perimeter area ratio of the park by designing compact layout (Figure 9). Of course, in urban planning and design there are many other aspects to be considered, such as existing ecological corridors, road network, residential areas, wind corridors, visual preferences;

(3) Add more parks (green spaces) in the area within high impervious surface ratio, in central urban area, represented by tall buildings and impervious surfaces of commercial and built-up areas. In addition, increase the park type of high cooling effect such as theme parks and urban parks in Zhengzhou.

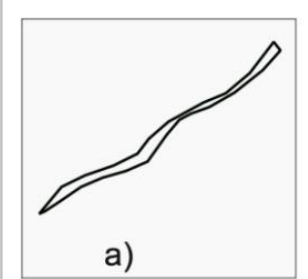

Paratio $=0.093$

Frac Dim $=1.52$

Area $=1.84$ ha

$\mathrm{PCl}=0.86{ }^{\circ} \mathrm{C}$

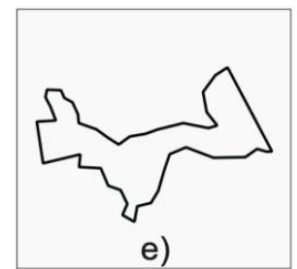

Paratio $=0.017$

Frac_Dim=1.34

Area $=19.00$ ha

$\mathrm{PCl}=2.43^{\circ} \mathrm{C}$

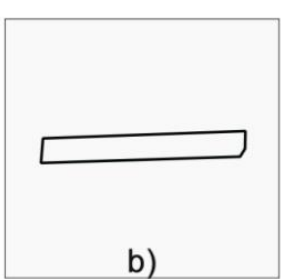

Paratio $=0.047$

Frac Dim $=1.30$

Area $=1.84$ ha

$\mathrm{PCl}=1.80^{\circ} \mathrm{C}$

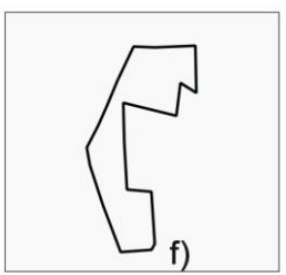

Paratio $=0.014$

Frac_Dim $=1.30$

Area $=21.11$ ha

$\mathrm{PCl}=2.89{ }^{\circ} \mathrm{C}$

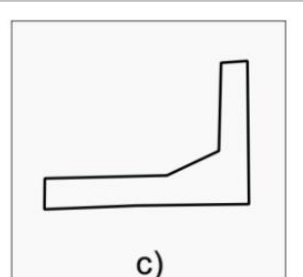

Paratio $=0.038$

Frac Dim=1.37

Area $=3.14$ ha

$\mathrm{PCl}=1.66^{\circ} \mathrm{C}$

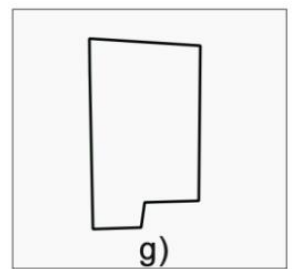

Paratio $=0.009$

Frac_Dim=1.24

Area $=21.24$ ha

$\mathrm{PCl}=3.16{ }^{\circ} \mathrm{C}$

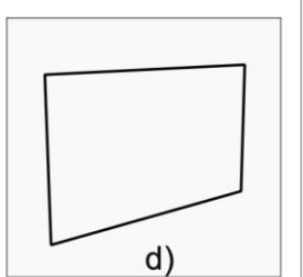

Paratio $=0.023$

Frac Dim=1.21

Area $=3.24$ ha

$\mathrm{PCl}=2.14{ }^{\circ} \mathrm{C}$

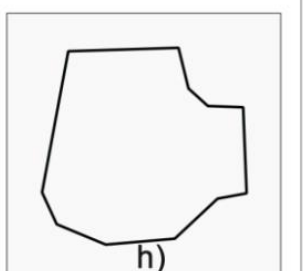

Paratio $=0.004$

Frac_Dim=1.20

Area $=79.40$ ha

$\mathrm{PCl}=2.52{ }^{\circ} \mathrm{C}$

Figure 9. Comparison of PCI with different fractal dimensions (Frac_Dim) and perimeter area ratios (Paratio). Typical park shapes with higher Frac_Dim and Paratio values $(\mathbf{a}, \mathbf{b}, \mathbf{e}, \mathbf{f}$,$) and typical shapes$ with lower Frac_Dim and Paratio values (c,d,g,h). 


\section{Conclusions}

This study used a comprehensive method to investigate the urban heat island phenomenon of Zhengzhou city in China. Using the radiative transfer equation (RTE) method to retrieve the LST and we analyzed the relation of particular factors to park LST and park cooling effect. The results of this paper give a reference to characterize the complex correlation between UHI and other factors in the expanding capital city of Henan province in China. The practical results can imply urban planners and stakeholders by providing scientific guidance for future urbanization and urban management. First, the results showed that parks have a cooling effect in the city, the mean LST of the park is $0.79{ }^{\circ} \mathrm{C}$ lower than in the city. Different park types have different cooling intensity. The theme park category in Zhengzhou has the highest cooling intensity with the $\mathrm{PCI}$ reaching $2.76^{\circ} \mathrm{C}$. The cooling intensity of the street park and linear parks is lower; with the $\mathrm{PCI}$ only reaching $0.8^{\circ} \mathrm{C}$ and $0.64{ }^{\circ} \mathrm{C}$, respectively. From the results of the park cooling effect analysis and its internal characteristics, we can recognize that the park LST depends mainly on the vegetation cover, waterbody and impervious surfaces in the park. Vegetation and water surface are the main factors of the park's cooling effect in Zhengzhou, but the impervious surface increases park LST. The study also shows a different linear correlation between the park LST and park patch metrics of Zhengzhou city. Park size and fractal dimension, perimeter area ratio affect park LST, while other geometric indicators such as shape index have no significant relation to the LST. Thus, we recommend for planners to maximize the park size and minimize perimeter area ratio to reduce the UHI effect.

The PCI is influenced by the park itself and its surrounding area:

(1) The characteristics of the park defined by its size, perimeter area ratio and fractal dimensions all affect the PCI directly. Because of these defining factors, there seems to be a positive correlation with FVC and NDWI, while NDISI has a negative impact on the PCI;

(2) The PCI is influenced by the surrounding land cover types coupled with the type of vegetation cover and water coverage. Because of these surrounding influences, the PCI has a directly proportional relationship to the surrounding impervious surface cover. A park's PCI has many factors to consider when understanding its mitigating effects on the UHI of its surrounding context. By first considering the factors that influence a park's temperature, we can start to change the cooling properties which help mitigate the UHI effects seen throughout cities.

We recommend additional planning consideration and construction of more parks in built-up urban areas among tall buildings and within large areas of impervious surfaces. Park types, such as theme parks and larger urban parks, should be considered with higher priority than above other park types.

Urban parks play an important role in the urban ecological environment. Targeted research on the cooling effect of parks has practical significance in urban planning and design. Parks with stronger cooling effects can help to reduce the adverse impacts of UHI problems. This study can provide a reference for urban planners and landscape architects as well as stakeholders and decision-makers.

Author Contributions: Data curation, H.L., G.T. and S.J.; Investigation, S.J.; Methodology, H.L.; resources, G.W.; software, H.L. and S.J.; supervision, S.J.; writing—original draft, H.L.; writing—review \& editing, G.T. and S.J. All authors have read and agreed to the published version of the manuscript.

Funding: This research was funded by "Henan Overseas Expertise Introduction Center for Discipline Innovation" and the APC was funded by Szent István University.

Acknowledgments: First, we would thank the Stipendium Hungaricum Programme founding for supporting my study and research. Second, we would also thank the colleagues in the Department of Landscape Planning and Regional Development, Szent István University. Third, thanks for the 6th Fábos Conference and land journal to organize this special issue. In addition, we would also like to thank the referees and the editors for their valuable comments for improving this manuscript. Finally, I would like to especially thank Malcolm Douglas Lambson and Eleanor Jessie Potgieter from the University of the Witwatersrand (South Africa), Kelvin Andrew Lasko from Montgomery Co. Public Schools (U.S.) for helping with the English revision of this article, Thank you very much for all your efforts. 
Conflicts of Interest: The authors declare no conflict of interest.

\section{References}

1. Howard, L. The Climate of London: Deduced from Meteorological Observations, Made at Different Places in the Neighbourhood of the Metropolis; W. Phillips: Cambridge, MA, USA, 1820; Volume 1.

2. Oke, T.R. City size and the urban heat island. Atmos. Environ. 1973, 7, 769-779. [CrossRef]

3. Stewart, I.D.; Oke, T.R.; Krayenhoff, E.S. Evaluation of the 'local climate zone' scheme using temperature observations and model simulations. Int. J. Climatol. 2014, 34, 1062-1080. [CrossRef]

4. Deilami, K.; Kamruzzaman, M.D.; Liu, Y. Urban heat island effect: A systematic review of spatio-temporal factors, data, methods, and mitigation measures. Int. J. Appl. Earth Obs. Geoinf. 2018, 67, 30-42. [CrossRef]

5. US EPA, O. Heat Island Effect. Available online: https://www.epa.gov/heat-islands (accessed on 17 October 2018).

6. Yu, Z.; Guo, X.; Zeng, Y.; Koga, M.; Vejre, H. Variations in land surface temperature and cooling efficiency of green space in rapid urbanization: The case of Fuzhou city, China. Urban For. Urban Green. 2018, 29, $113-121$. [CrossRef]

7. Gray, G. EPA's 2008 Report on the Environment; United States Environmental Protection Agency: Washington, DC, USA, 2008.

8. Voogt, J.A.; Oke, T.R. Thermal remote sensing of urban climates. Remote Sens. Environ. 2003, 86, 370-384. [CrossRef]

9. Oke, T.R. Boundary Layer Climates, 1st ed.; Taylor and Francis Group: New York, NY, USA, 1987.

10. Yuan, F.; Bauer, M.E. Comparison of impervious surface area and normalized difference vegetation index as indicators of surface urban heat island effects in Landsat imagery. Remote Sens. Environ. 2007, 106, 375-386. [CrossRef]

11. Li, J.; Song, C.; Cao, L.; Zhu, F.; Meng, X.; Wu, J. Impacts of landscape structure on surface urban heat islands: A case study of Shanghai, China. Remote Sens. Environ. 2011, 115, 3249-3263. [CrossRef]

12. Mohamed, A.A.; Odindi, J.; Mutanga, O. Land surface temperature and emissivity estimation for Urban Heat Island assessment using medium- and low-resolution space-borne sensors: A review. Geocarto Int. 2017, 32, 455-470. [CrossRef]

13. Jiang, J.; Tian, G. Analysis of the impact of Land use/Land cover change on Land Surface Temperature with Remote Sensing. Procedia Environ. Sci. 2010, 2, 571-575. [CrossRef]

14. Zhao, H.; Ren, Z.; Tan, J. The Spatial Patterns of Land Surface Temperature and Its Impact Factors: Spatial Non-Stationarity and Scale Effects Based on a Geographically-Weighted Regression Model. Sustainability 2018, 10, 2242. [CrossRef]

15. Kawashima, S.; Ishida, T.; Minomura, M.; Miwa, T. Relations between Surface Temperature and Air Temperature on a Local Scale during Winter Nights. J. Appl. Meteorol. 2000, 39, 1570-1579. [CrossRef]

16. Doick, K.J.; Peace, A.; Hutchings, T.R. The role of one large greenspace in mitigating London's nocturnal urban heat island. Sci. Total Environ. 2014, 493, 662-671. [CrossRef] [PubMed]

17. Yan, H.; Wu, F.; Dong, L. Influence of a large urban park on the local urban thermal environment. Sci. Total Environ. 2018, 622-623, 882-891. [CrossRef] [PubMed]

18. Yu, Z.; Xu, S.; Zhang, Y.; Jørgensen, G.; Vejre, H. Strong contributions of local background climate to the cooling effect of urban green vegetation. Sci. Rep. 2018, 8, 6798. [CrossRef] [PubMed]

19. Lindén, J.; Fonti, P.; Esper, J. Temporal variations in microclimate cooling induced by urban trees in Mainz, Germany. Urban For. Urban Green. 2016, 20, 198-209. [CrossRef]

20. Yahia, M.W.; Johansson, E.; Thorsson, S.; Lindberg, F.; Rasmussen, M.I. Effect of urban design on microclimate and thermal comfort outdoors in warm-humid Dar es Salaam. Tanzan. Int. J. Biometeorol. 2018, 62, 373-385. [CrossRef] [PubMed]

21. Chatterjee, S.; Khan, A.; Dinda, A.; Mithun, S.; Khatun, R.; Akbari, H.; Kusaka, H.; Mitra, C.; Bhatti, S.S.; Doan, Q.V.; et al. Simulating micro-scale thermal interactions in different building environments for mitigating urban heat islands. Sci. Total Environ. 2019, 663, 610-631. [CrossRef]

22. US EPA, O. Learn About Heat Islands. Available online: https://www.epa.gov/heat-islands/learn-about-heatislands (accessed on 17 October 2018). 
23. Ng, E.; Chen, L.; Wang, Y.; Yuan, C. A study on the cooling effects of greening in a high-density city: An experience from Hong Kong. Build. Environ. 2012, 47, 256-271. [CrossRef]

24. Rasul, A.; Balzter, H.; Smith, C.; Remedios, J.; Adamu, B.; Sobrino, J.; Srivanit, M.; Weng, Q. A Review on Remote Sensing of Urban Heat and Cool Islands. Land 2017, 6, 38. [CrossRef]

25. Oliveira, S.; Andrade, H.; Vaz, T. The cooling effect of green spaces as a contribution to the mitigation of urban heat: A case study in Lisbon. Build. Environ. 2011, 46, 2186-2194. [CrossRef]

26. Du, H.; Cai, W.; Xu, Y.; Wang, Z.; Wang, Y.; Cai, Y. Quantifying the cool island effects of urban green spaces using remote sensing Data. Urban For. Urban Green. 2017, 27, 24-31. [CrossRef]

27. Cao, X.; Onishi, A.; Chen, J.; Imura, H. Quantifying the cool island intensity of urban parks using ASTER and IKONOS data. Landsc. Urban Plan. 2010, 96, 224-231. [CrossRef]

28. Lin, W.; Yu, T.; Chang, X.; Wu, W.; Zhang, Y. Calculating cooling extents of green parks using remote sensing: Method and test. Landsc. Urban Plan. 2015, 134, 66-75. [CrossRef]

29. Kawashima, S. Effect of vegetation on surface temperature in urban and suburban areas in winter. Energy Build. 1990, 15, 465-469. [CrossRef]

30. Weng, Q.; Lu, D.; Schubring, J. Estimation of land surface temperature-vegetation abundance relationship for urban heat island studies. Remote Sens. Environ. 2004, 89, 467-483. [CrossRef]

31. Chen, X.-L.; Zhao, H.-M.; Li, P.-X.; Yin, Z.-Y. Remote sensing image-based analysis of the relationship between urban heat island and land use/cover changes. Remote Sens. Environ. 2006, 104, 133-146. [CrossRef]

32. Gartland, L. Heat Islands: Understanding and Mitigating Heat in Urban Areas; Earthscan: London, UK, 2008.

33. Liu, H.; Weng, Q. Seasonal variations in the relationship between landscape pattern and land surface temperature in Indianapolis, USA. Environ. Monit. Assess. 2008, 144, 199-219. [CrossRef]

34. Li, J.; Wang, X.; Wang, X.; Ma, W.; Zhang, H. Remote sensing evaluation of urban heat island and its spatial pattern of the Shanghai metropolitan area, China. Ecol. Complex. 2009, 6, 413-420. [CrossRef]

35. Estoque, R.C.; Murayama, Y.; Myint, S.W. Effects of landscape composition and pattern on land surface temperature: An urban heat island study in the megacities of Southeast Asia. Sci. Total Environ. 2017, 577, 349-359. [CrossRef]

36. Kolokotroni, M.; Giridharan, R. Urban heat island intensity in London: An investigation of the impact of physical characteristics on changes in outdoor air temperature during summer. Sol. Energy 2008, 82, 986-998. [CrossRef]

37. Kato, S.; Hiyama, K. Ventilating Cities: Air-Flow Criteria for Healthy and Comfortable Urban Living; Springer Science \& Business Media: Berlin, Germany, 2012.

38. Kanda, M.; Moriizumi, T. Momentum and Heat Transfer over Urban-like Surfaces. Bound. Layer Meteorol. 2009, 131, 385-401. [CrossRef]

39. Monteith, J.L.; Unsworth, M.H. Principles of Environmental Physics: Plants, Animals, and the Atmosphere, 4th ed.; Elsevier/Academic Press: Amsterdam, The Netherlands, 2013.

40. Kotthaus, S.; Grimmond, C.S.B. Energy exchange in a dense urban environment-Part I: Temporal variability of long-term observations in central London. Urban Clim. 2014, 10, 261-280. [CrossRef]

41. Min, M.; Zhao, H.; Miao, C. Spatio-Temporal Evolution Analysis of the Urban Heat Island: A Case Study of Zhengzhou City, China. Sustainability 2018, 10, 1992. [CrossRef]

42. Wang, Z.; Mao, P.; Yang, H.; Zhao, Y.; He, T.; Dawson, R.J.; Li, Z. Measuring the Urban Land Surface Temperature Variations in Zhengzhou City Using the Landsat-Like Data. Available online: https://www. preprints.org/manuscript/201809.0192/v1 (accessed on 17 October 2018).

43. Urban construction over the years-Zhengzhou Statistics Bureau. Available online: http://tj.zhengzhou.gov. cn/ndsj/216688.jhtml (accessed on 17 October 2018).

44. Mu, B.; Mayer, A.L.; He, R.; Tian, G. Land use dynamics and policy implications in Central China: A case study of Zhengzhou. Cities 2016, 58, 39-49. [CrossRef]

45. Price, J.C. Estimating surface temperatures from satellite thermal infrared data-A simple formulation for the atmospheric effect. Remote Sens. Environ. 1983, 13, 353-361. [CrossRef]

46. Zhou, J.; Li, J.; Zhang, L.; Hu, D.; Zhan, W. Intercomparison of methods for estimating land surface temperature from a Landsat-5 TM image in an arid region with low water vapour in the atmosphere. Int. J. Remote Sens. 2012, 33, 2582-2602. [CrossRef] 
47. Sekertekin, A. Validation of Physical Radiative Transfer Equation-Based Land Surface Temperature Using Landsat 8 Satellite Imagery and SURFRAD in-situ Measurements. J. Atmos. Sol. Terr. Phys. 2019, 196, 105161. [CrossRef]

48. Sobrino, J.A.; Jimenez-Munoz, J.C. Minimum configuration of thermal infrared bands for land surface temperature and emissivity estimation in the context of potential future missions. Remote Sens. Environ. 2014, 148, 158-167. [CrossRef]

49. Department of the Interior, U.S. Geological Survey Landsat 8 Data Users Handbook. Available online: https://www.usgs.gov/land-resources/nli/landsat/landsat-8-data-users-handbook (accessed on 17 October 2018).

50. Carlson, T.N.; Ripley, D.A. On the relation between NDVI, fractional vegetation cover, and leaf area index. Remote Sens. Environ. 1997, 62, 241-252. [CrossRef]

51. Spronken-Smith, R.A.; Oke, T.R. The thermal regime of urban parks in two cities with different summer climates. Int. J. Remote Sens. 1998, 19, 2085-2104. [CrossRef]

52. Chang, C.-R.; Li, M.-H.; Chang, S.-D. A preliminary study on the local cool-island intensity of Taipei city parks. Landsc. Urban Plan. 2007, 80, 386-395. [CrossRef]

53. Li, Y.; Zhang, H.; Kainz, W. Monitoring patterns of urban heat islands of the fast-growing Shanghai metropolis, China: Using time-series of Landsat TM/ETM+ data. Int. J. Appl. Earth Obs. Geoinf. 2012, 19, 127-138. [CrossRef]

54. Leitao, A.B.; Miller, J.; Ahern, J.; McGarigal, K. Measuring Landscapes: A Planner's Handbook; Island Press: Washington, DC, USA, 2012; ISBN 978-1-59726-772-4.

55. Gao, B. NDWI-A normalized difference water index for remote sensing of vegetation liquid water from space. Remote Sens. Environ. 1996, 58, 257-266. [CrossRef]

56. Kikon, N.; Singh, P.; Singh, S.K.; Vyas, A. Assessment of urban heat islands (UHI) of Noida City, India using multi-temporal satellite data. Sustain. Cities Soc. 2016, 22, 19-28. [CrossRef]

57. $\mathrm{Xu}, \mathrm{H}$. Analysis of impervious surface and its impact on urban heat environment using the normalized difference impervious surface index (NDISI). Photogramm. Eng. Remote Sens. 2010, 76, 557-565. [CrossRef]

58. Zhang, Y.; Odeh, I.O.A.; Ramadan, E. Assessment of land surface temperature in relation to landscape metrics and fractional vegetation cover in an urban/peri-urban region using Landsat data. Int. J. Remote Sens. 2013, 34, 168-189. [CrossRef]

59. Han-qiu, X. A Study on Information Extraction of Water Body with the Modified Normalized Difference Water Index (MNDWI). J. Remote Sens. 2005, 9, 589-595.

60. Bowen, I.S. The Ratio of Heat Losses by Conduction and by Evaporation from any Water Surface. Phys. Rev. 1926, 27, 779-787. [CrossRef]

61. Jiang, Z.; Huete, A.R.; Chen, J.; Chen, Y.; Li, J.; Yan, G.; Zhang, X. Analysis of NDVI and scaled difference vegetation index retrievals of vegetation fraction. Remote Sens. Environ. 2006, 101, 366-378. [CrossRef]

62. $\mathrm{Xu}, \mathrm{H}$. Modification of normalised difference water index (NDWI) to enhance open water features in remotely sensed imagery. Int. J. Remote Sens. 2006, 27, 3025-3033. [CrossRef]

63. Sun, Z.; Wang, C.; Guo, H.; Shang, R. A Modified Normalized Difference Impervious Surface Index (MNDISI) for Automatic Urban Mapping from Landsat Imagery. Remote Sens. 2017, 9, 942. [CrossRef]

64. Wang, Y.; Bakker, F.; de Groot, R.; Wörtche, H. Effects of urban green infrastructure (UGI) on local outdoor microclimate during the growing season. Environ. Monit. Assess. 2015, 187, 732. [CrossRef] [PubMed]

65. Antoniadis, D.; Katsoulas, N.; Kittas, C. Simulation of schoolyard's microclimate and human thermal comfort under Mediterranean climate conditions: Effects of trees and green structures. Int. J. Biometeorol. 2018, 62, 2025-2036. [CrossRef] [PubMed]

(C) 2020 by the authors. Licensee MDPI, Basel, Switzerland. This article is an open access article distributed under the terms and conditions of the Creative Commons Attribution (CC BY) license (http://creativecommons.org/licenses/by/4.0/). 